\title{
Glacier mass balance reconstruction by sublimation induced enrichment of chemical species on Cerro Tapado (Chilean Andes)
}

\author{
P. Ginot ${ }^{1,2,{ }^{*}}$, C. Kull ${ }^{3}$, U. Schotterer ${ }^{1,4}$, M. Schwikowski ${ }^{2}$, and H. W. Gäggeler ${ }^{1,2}$ \\ ${ }^{1}$ Department of Chemistry and Biochemistry, University of Bern, Freiestrasse 3, CH-3012 Bern, Switzerland \\ ${ }^{2}$ Paul Scherrer Institute, CH-5232 Villigen PSI, Switzerland \\ ${ }^{3}$ PAGES International Project Office, Sulgeneckstrasse 38, CH-3007 Bern, Switzerland \\ ${ }^{4}$ Physics Institute, University of Bern, Sidlerstrasse 5, CH-3012 Bern, Switzerland \\ *now at: IRD Great Ice/LGGE 54, rue Molière, 38402 St Martin d'Hères Cedex, France
}

Received: 8 September 2005 - Published in Clim. Past Discuss.: 22 September 2005

Revised: 5 December 2005 - Accepted: 3 April 2006 - Published: 23 May 2006

\begin{abstract}
A $36 \mathrm{~m}$ long ice core down to bedrock from the Cerro Tapado glacier ( $5536 \mathrm{~m}$ a.s. $1,30^{\circ} 08^{\prime} \mathrm{S}, 69^{\circ} 55^{\prime} \mathrm{W}$ ) was analyzed to reconstruct past climatic conditions for Northern Chile. Because of the marked seasonality in the precipitation (short wet winter and extended dry summer periods) in this region, major snow ablation and related postdepositional processes occur on the glacier surface during summer periods. They include predominantly sublimation and dry deposition. Assuming that, like measured during the field campaign, the enrichment of chloride was always related to sublimation, the chemical record along the ice core may be applied to reconstruct the history of such secondary processes linked to the past climatic conditions over northern Chile. For the time period 1962-1999, a mean annual net accumulation of $316 \mathrm{~mm}$ water equivalent (weq) and $327 \mathrm{~mm}$ weq loss by sublimation was deduced by this method. This corresponds to an initial total annual accumulation of $539 \mathrm{~mm}$ weq. The annual variability of the accumulation and sublimation is related with the Southern Oscillation Index (SOI): higher net-accumulation during El-Niño years and more sublimation during La Niña years. The deepest part of the ice record shows a time discontinuity; with an ice body deposited under different climatic conditions: $290 \mathrm{~mm}$ higher precipitation but with reduced seasonal distribution $\left(+470 \mathrm{~mm}\right.$ in winter and $-180 \mathrm{~mm}$ in summer) and $-3^{\circ} \mathrm{C}$ lower mean annual temperature. Unfortunately, its age is unknown. The comparison with regional proxy data however let us conclude that the glacier buildup did most likely occur after the dry mid-Holocene.
\end{abstract}

Correspondence to: P. Ginot (ginot@lgge.obs.ujf-grenoble.fr)

\section{Introduction}

In order to determine the mass balance of a glacier, net accumulation consisting of accumulation and ablation of a given hydrological year is usually measured using a network of stakes and/or snow pits. This method has been used e.g. in the Alps to reconstruct mass balance over several decades, but it requires regular field measurements. In the South American Andes, the mass balances of some glaciers such as the Zongo glacier $\left(16^{\circ} 15^{\prime} \mathrm{S}, 68^{\circ} 10^{\prime} \mathrm{W}\right)$ and Echaurren Norte $\left(33^{\circ} 35^{\prime} \mathrm{S}, 70^{\circ} 08^{\prime} \mathrm{W}\right)$ have been monitored since 1991 and 1975, respectively (see e.g. Francou et al., 2000, 2003; Escobar et al., 1995). Ice cores may be applied to reconstruct past mass balance. In addition, they provide information on past meteorological conditions, climate change and atmospheric composition (e.g. Bradley, 1999). Over the last two decades, several South-American glaciers and associated ice cores have been investigated, including Quelccaya (Peru) (e.g. Thompson et al., 1985), Huascarán (Peru) (e.g. Thompson et al., 1995), Sajama (Bolivia) (Thompson et al., 1998) and Illimani (Bolivia) (Knüsel et al., 2002; De Angelis et al., 2003; Correia et al., 2003).

In this study, an ice core from Cerro Tapado glacier (5536 m a.s.1., $30^{\circ} 08^{\prime} \mathrm{S}, 69^{\circ} 55^{\prime} \mathrm{W}$, Fig. 1), was investigated in order to reconstruct the history of this glacier's mass balance. Cerro Tapado is located in the Norte Chico region of Chile, near the southern boundary of the "South American Arid Diagonal". This glacier represents a unique archive for paleoclimatic reconstruction in this otherwise unglaciated high mountain area. However, the Cerro Tapado record indicates that interpretation of ice cores retrieved in such dry areas is not straightforward because large sublimation losses influence the mass balance and the record of trace species.

Published by Copernicus GmbH on behalf of the European Geosciences Union. 
Table 1. Modern climate conditions on Cerro Tapado at $4000 \mathrm{~m}$ a.s.1. (Kull et al., 2002).

\begin{tabular}{lllllll}
\hline & $\begin{array}{l}\text { Precipitation } \mathrm{d}, \mathrm{f} \\
\left(\mathrm{mm} \mathrm{y}^{-1}\right)\end{array}$ & $\begin{array}{l}\text { Temperature } \\
\left({ }^{\circ} \mathrm{C}\right)\end{array}$ & $\begin{array}{l}\text { Radiation }^{\mathrm{a}, \mathrm{f}} \\
\left(\mathrm{kwh} \mathrm{m}^{-2} \mathrm{~d}^{-1}\right)\end{array}$ & $\begin{array}{l}\text { Wind a,b,c } \\
\left(\mathrm{m} \mathrm{s}^{-1}\right)\end{array}$ & $\begin{array}{l}\text { Rel. hum. }{ }^{\mathrm{a}, \mathrm{b}, \mathrm{c}} \\
(\%)\end{array}$ & $\begin{array}{l}\text { Cloudiness } \\
(\%)\end{array}$ \\
\hline $\begin{array}{l}\text { Annual mean } \\
\text { Annual amplitude }\end{array}$ & $\begin{array}{l}400 \\
100 \mathrm{~mm} \text { in }\end{array}$ & -0.4 & 5.62 & 4.36 & 28 & 15 \\
$\begin{array}{l}\text { Daily amplitude } \\
\text { Lapse rate }(/ 100 \mathrm{~m})\end{array}$ & 12 & 2.1 & 2 & 3 & 5 \\
\hline
\end{tabular}

a Tapado $4215 \mathrm{~m}\left(30^{\circ} 08^{\prime} \mathrm{S} / 69^{\circ} 55^{\prime} \mathrm{W} ; 1998-1999\right)$

b El Laco $4400 \mathrm{~m}\left(23^{\circ} 50^{\prime} \mathrm{S} / 67^{\circ} 29^{\prime} \mathrm{W} ; 1990-1994\right)$

${ }^{c}$ El Laco $5000 \mathrm{~m}\left(23^{\circ} 50^{\prime} \mathrm{S} / 67^{\circ} 29^{\prime} \mathrm{W}\right.$; 1990-1994)

d Minetti et al. (1986)

e Ammann (1996)

f Vuille (1996)

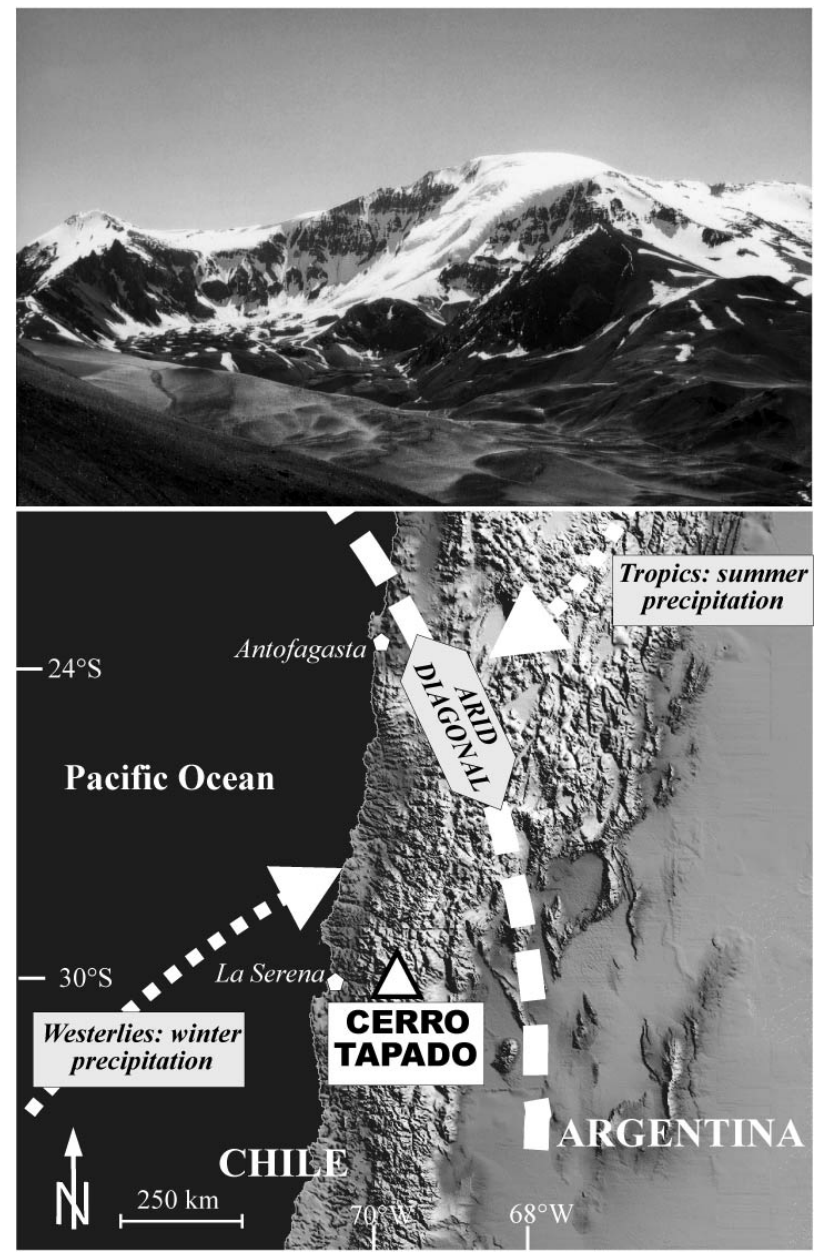

Fig. 1. Location of Cerro Tapado in Northern Chile. The South American Arid Diagonal separates both principal precipitation regimes that influence this region (Westerlies and Tropics). On the top, a photo of the glacier on Cerro Tapado.
The climate of this part of the South American continent is primarily driven by the Pacific. On the western side of the Andes, south of $18^{\circ} \mathrm{S}$, the precipitation at $4000 \mathrm{~m}$ a.s. 1 increases from north to south, reaching values of about $400 \mathrm{~mm} \mathrm{y}^{-1}$ at $30^{\circ} \mathrm{S}$ (Escobar and Aceituno, 1998). Table 1 presents the modern climatic conditions on Cerro Tapado. Winter precipitation (MJJA) related to Pacific cyclone activity is dominant. The summer months (SONDJFM) are relatively dry, although sporadically interrupted by convective showers from the continental eastern side of the Andes (Begert, 1999; Escobar and Aceituno, 1998). The modern climatic conditions and the strong N-S precipitation gradient allow the presence of isolated glaciers only south of $27^{\circ} \mathrm{S}$, where the Equilibrium Line Altitudes (ELA) decrease from $5900 \mathrm{~m}$ a.s.l. at $27^{\circ} \mathrm{S}$ to $5300 \mathrm{~m}$ a.s.l. at $30^{\circ} \mathrm{S}$ and to $4500 \mathrm{~m}$ a.s.l. at $32^{\circ} \mathrm{S}$ (e.g. Amman et al., 2001. The Cerro Tapado glacier flows down from the summit (5536 m a.s.l.) to $4600 \mathrm{~m}$ a.s.l. and exists under limiting moisture conditions (see picture in Fig. 1). Higher peaks adjacent to Cerro Tapado, such as Cerro Olivares (6252 m a.s.l, $30^{\circ} 17^{\prime} \mathrm{S}$, $69^{\circ} 54^{\prime} \mathrm{W}$ ), are currently free of glaciers, suggesting that some of the existing glaciers are atypical in this area and that local conditions (e.g. excess precipitation, wind transport, topography) play an important role (Kull et al., 2002).

During the dry season, effects of post depositional processes, such as sublimation of surface snow, volatilization of some chemical species, and dry deposition of mineral particles (Ginot et al., 2001a; Hardy et al., 2001) significantly perturb the chemical composition of surface snow. In addition, the percolation of surface meltwater may alter the snow composition (e.g. Hou et al., 2002; Schotterer et al., 2005). By means of a surface snow experiment performed during the dry season on Cerro Tapado, Ginot et al. (2001a) demonstrated that chemical species irreversibly trapped in the snow are significantly enriched in the surface layer by sublimation of the water matrix and by dry deposition. Species present in 


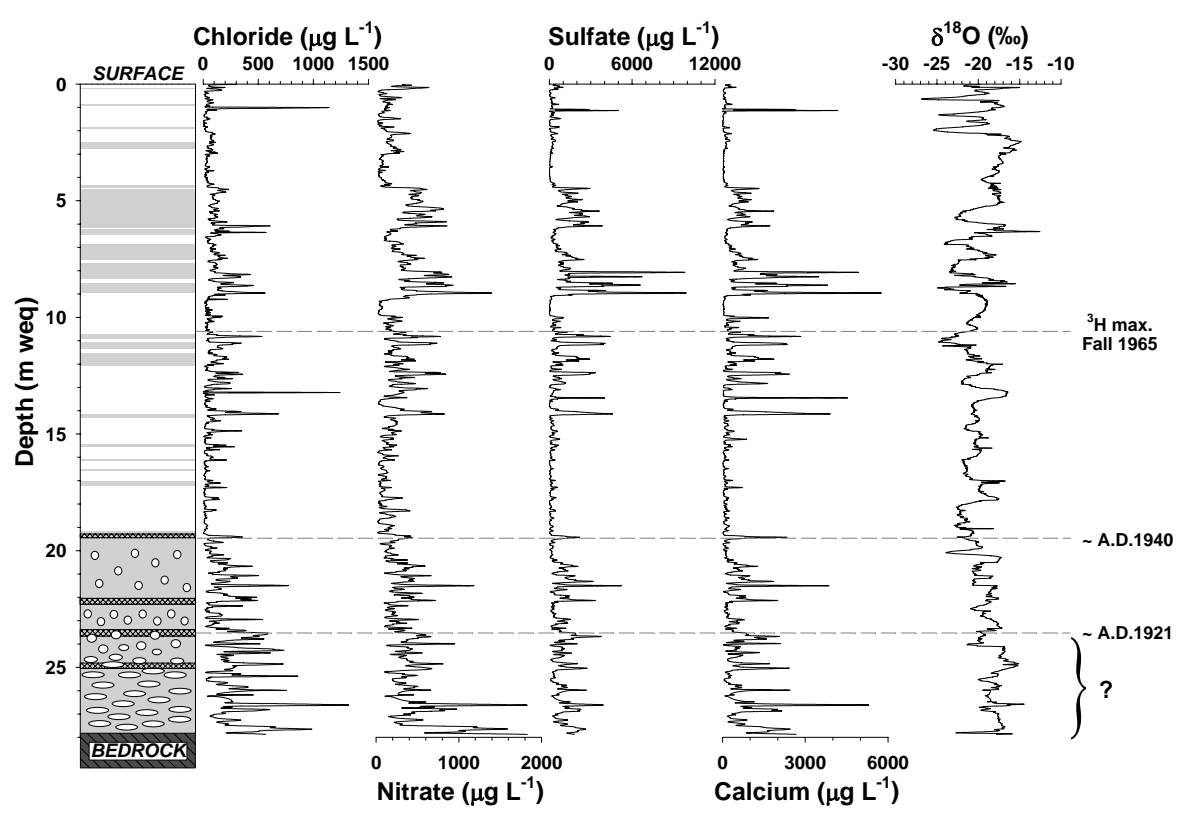

Fig. 2. Cerro Tapado ice core: stratigraphy [firn (white), ice (grey), dust layer (hatched black), air bubble shape (white circles and ellipses)] and concentrations profiles of chloride, nitrate, sulfate, calcium and $\delta^{18} \mathrm{O}$. A few time horizons are indicated. The age of the lowermost $4.5 \mathrm{~m}$ weq is unknown (see text).

a volatile form were partially released from the snow. This experiment also revealed that the concentration of certain chemical species in the surface snow layer is directly proportional to the amount of water lost by sublimation, without observed influence of dry deposition. In the case of Cerro Tapado, the best tracer for the reconstruction of sublimation turned out to be chloride.

This relation will be used to reconstruct the original mass balance from the trace species concentration recorded along the Cerro Tapado ice core. Further, the temporal variation of the deduced mass balance is compared to the El NiñoSouthern Oscillation Index (SOI).

\section{Experimental}

In February 1999, a $36 \mathrm{~m}$ long ice core $(27.87 \mathrm{~m}$ weq) was recovered from the Cerro Tapado glacier with the FELICS solar-powered electromechanical ice drill (Ginot et al., 2002). The core reached bed rock. All ice core segments were kept frozen until they were analyzed. Englacial temperatures were measured in the borehole using a thermistor chain. Between February 1998 and February 2000, an automated weather station installed near the Cerro Tapado base camp (4215 $\mathrm{m}$ a.s. $1,30^{\circ} 08^{\prime} \mathrm{S}, 69^{\circ} 55^{\prime} \mathrm{W}$ ) measured incoming global radiation, wind speed, humidity and temperature. A second station was operated on the summit plateau of the glacier at $5500 \mathrm{~m}$ a.s.l. during the ice-coring campaign in February 1999 (Ginot et al., 2001a; Kull et al., 2002; Stichler et al., 2001).
The ice core was cut into 1901 samples $(1.9 \pm 0.5 \mathrm{~cm}$ resolution) in a cold room and analyzed for concentrations of major ions $\left(\mathrm{Na}^{+}, \mathrm{K}^{+}, \mathrm{Mg}^{2+}, \mathrm{Ca}^{2+}, \mathrm{NH}_{4}^{+}, \mathrm{SO}_{4}^{2-}, \mathrm{NO}_{3}^{-}, \mathrm{Cl}^{-}\right.$, $\mathrm{CH}_{3} \mathrm{SO}_{3}^{-}, \mathrm{F}^{-}, \mathrm{HCO}_{2}^{-}, \mathrm{CH}_{3} \mathrm{CO}_{2}^{-}, \mathrm{C}_{2} \mathrm{O}_{4}^{2-}$ ) (see e.g. Ginot et al., 2001a), $\mathrm{pH}$, conductivity and stable isotopes $\left(\delta^{2} \mathrm{H}\right.$ and $\left.\delta^{18} \mathrm{O}\right)$. Firn/ice density was measured for each $70 \mathrm{~cm}$ long core segment.

During the same period, a surface snow experiment was conducted on a flat snow area close to the drilling site. From a virgin snow surface not affected by previous sublimation and dry deposition effects, $1 \mathrm{~cm}$ thick snow samples were collected twice a day during about 4 days in order to observe surface snow chemical concentration and isotopic composition changes. For the same time period, sublimation was directly measured by sublimation pans and appropriate meteorological data were collected. The complete experiment and their results are described in detail in Ginot et al. (2001a) and Stichler et al. (2001).

\section{Results}

The annual mean temperature recorded between 1998 and 2000 at $4215 \mathrm{~m}$ a.s.l was $-0.4^{\circ} \mathrm{C}$. Table 1 presents annual means, annual amplitude, daily amplitude and lapse rates of all measured meteorological parameters (temperature, precipitation, radiation, wind speed, relative humidity, and cloudiness).

An ice core stratigraphy with major ice lenses, dust layers and the shape of the air bubbles is illustrated in Fig. 2, 


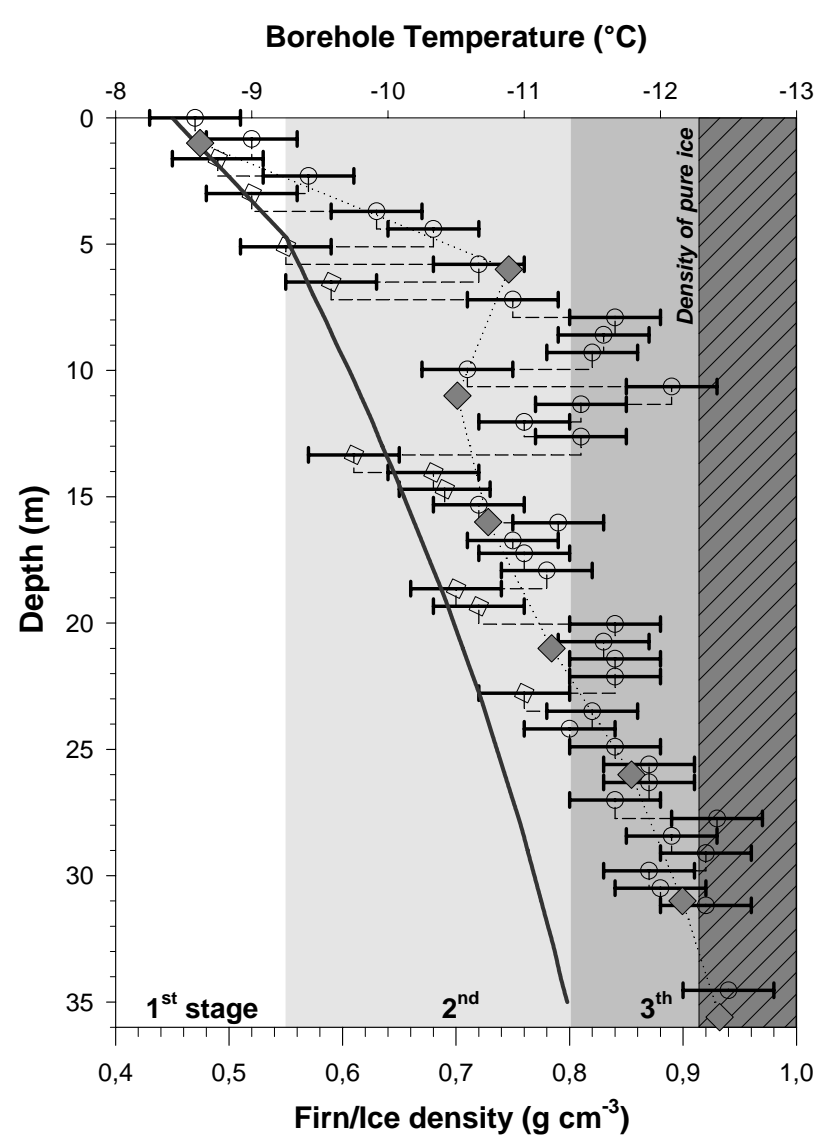

Fig. 3. Borehole temperature in ${ }^{\circ} \mathrm{C}$ (grey diamonds) and firn/ice density. The black circles represent the density of segments with ice lenses formed by refreezing meltwater, and white squares represent the density of segments without. The thick black line is the modeled density for the 1st and 2nd stages of densification, until a density of $0.8 \mathrm{~g} \mathrm{~cm}^{-3}$ (Herron and Langway, 1980).

together with selected ion concentration profiles $\left(\mathrm{Cl}^{-}, \mathrm{NO}_{3}^{-}\right.$, $\left.\mathrm{SO}_{4}^{2-}, \mathrm{Ca}^{2+}\right)$ and the $\delta^{18} \mathrm{O}$ record. The borehole temperatures ranged from $-8.6^{\circ} \mathrm{C}(1 \mathrm{~m}$ depth $)$ to $-12.4^{\circ} \mathrm{C}$ (bedrock), see Fig. 3. The low glacier temperature suggests a good preservation of the chemical and isotopic profiles without major disturbances due to meltwater percolation. The basal temperature indicates that the deepest ice is frozen to bedrock. The firn/ice density profile measured from $70 \mathrm{~cm}$ long core sections (Fig. 3) exhibits strong and unusual variations. Only for some core segments consisting mainly of firn (white squares in Fig. 3) does the density profile agree well with the predicted values obtained from a firn densification model (Herron and Langway, 1980) (black line in Fig. 3, details in section "Melting"). The core segments containing ice lenses (black circles in Fig. 3) have significant positive density anomalies.

For the ice core dating, a combination of several conventional dating methods was used (identification of tritium hori- zon, annual layer counting, ${ }^{210} \mathrm{~Pb}$ decay) (e.g. Eichler et al., 2000). The peak of the tritium activity, which in the Southern hemisphere occurred during the years 1965/66 (Schotterer et al., 1998), was found between 10.68 and $10.77 \mathrm{~m}$ water equivalent (m weq) depth. This reference horizon yields a mean annual net-accumulation of $315 \mathrm{~mm}$ weq $\mathrm{y}^{-1}$. Between 1963 and 1999, a seasonal (wet-dry seasons) dating resolution is achieved, based on a selective combination of annual variations of the tritium activity (1963-1970), some chemical species $\left(\mathrm{NO}_{3}^{2-}, \mathrm{Ca}^{2+}\right)$ and $\delta^{18} \mathrm{O}$ (Ginot et al., $2001 \mathrm{~b})$. The concentration peaks of ions were attributed to the dry season (September to March) when sublimation increases the concentration of some conservative ions in the surface snow layers (Ginot et al., 2001a). Sublimation also influences the stable isotope profiles (Stichler et al., 2001). The wet seasons (April to August) are identified by lower ion concentrations due to much less sublimation. With only two reference horizons (surface and tritium maximum), the precision of the dating decreases to \pm 2 years for the period 1967-1977. For the deeper part of the record, we try to use the dating method based on ${ }^{210} \mathrm{~Pb}$ activity decay but without success. ${ }^{210} \mathrm{~Pb}$ activity decreases from $71 \mathrm{mBq} \mathrm{kg}^{-1}$ at the surface to a mean background level of approx $3.4 \mathrm{mBq} \mathrm{kg}^{-1}$ at $\sim 21 \mathrm{~m}$ weq, hence covering a time range of about one century due to the half-life of $22.3 \mathrm{y}$ for ${ }^{210} \mathrm{~Pb}$. The background level reflects the blank value of the procedure, and was subtracted from the values for the determination of the depth-age relation. With these parameters, the age based on ${ }^{210} \mathrm{~Pb}$ was 1927 for he well defined 1965 tritium level. Deeper than the tritium reference level, only annual layers counting method was used for dating but with some uncertainty.

\subsection{Mass balance reconstruction}

\subsubsection{Net-accumulation}

Annual net-accumulation is the quantity of snow preserved during the hydrological year, from beginning of the wet season to the end of the following dry season (March to February). It is determined by identifying annual layers, as explained above for the period 1963 to 1999 . For the lower part only multi annual means can be given, calculated for intervals, each $1 \mathrm{~m}$ weq long. Table 2 and Fig. 4a (top) summarize the results. For the period 1963-1999, the annual net-accumulation rate fluctuates between 102 (in 1980) and $1032 \mathrm{~mm}$ weq (in 1966) with a mean value of $316 \mathrm{~mm}$ weq. The same amplitude in the net-accumulation rates was observed previously in ice core records from Illimani, Chimborazo, Quelccaya and Huascarán.

\subsubsection{Sublimation}

As mentioned above, some ions are irreversibly trapped in the snow, resulting in a significantly enriched surface layer due to sublimation of the water matrix $\left(\mathrm{Cl}^{-}, \mathrm{SO}_{4}^{2-}\right.$, and $\left.\mathrm{K}^{+}\right)$ 
Table 2. Mass balance terms net accumulation, sublimation, melt, and total accumulation reconstructed from the ice core.

\begin{tabular}{lllllllll}
\hline Period & Value & \multicolumn{2}{c}{ Net-accumulation } & & Sublimation & Melt & \multicolumn{2}{c}{ Total-accumulation } \\
\hline & & Annual & 1 meter & Annual & 1 meter & 1 meter & Annual & 1 meter \\
\hline $1999-1962$ & Mean & 316 & 347 & 327 & 283 & 40 & 539 & 553 \\
& Min & 102 & $200(-18)$ & 1 & $24(-5)$ & $8(-1)$ & 160 & $335(-37)$ \\
& Max & 1032 & $500(+167)$ & 1237 & $667(+74)$ & $122(+40)$ & 1985 & $851(+284)$ \\
$1962-23.5$ m weq & Mean & & 306 & & 374 & 33 & 681 \\
& Min & & $167(-13)$ & & $37(-8)$ & $4(-1)$ & $384(-35)$ \\
& Max & & $500(+167)$ & & $880(+294)$ & $63(+20)$ & $1380(+460)$ \\
\hline \multirow{2}{*}{23.5 m weq - Bedrock } & Mean & & 263 & & 1374 & & 1310 \\
& Min & & $218(-24)$ & & $982(-109)$ & & & $586(-53)$ \\
& Max & $333(+67)$ & & $1807(+360)$ & & $1960(+178)$
\end{tabular}

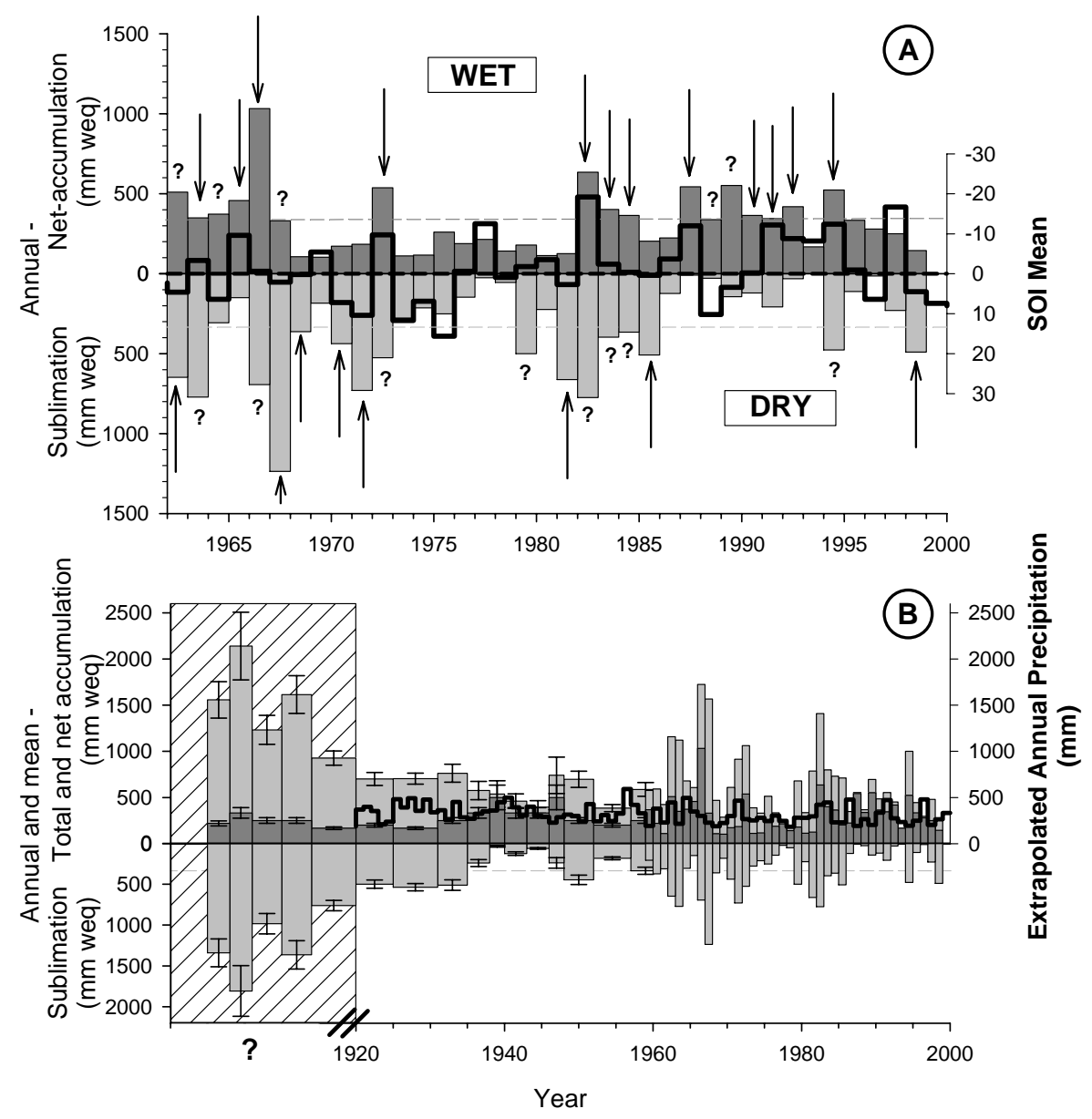

Fig. 4. (a) Measured annual net-accumulation and reconstructed sublimation deduced from the ice core are compared with the Southern Oscillation Index (SOI, thick line) for the time period 1962-1999 with annual resolution. The arrows show the years when above average annual net-accumulation values correspond to ENSO wet phase (WET window), and the years when above average sublimation values correspond to ENSO dry phase (DRY window). (b) Net-accumulation, reconstructed sublimation, and total accumulation (which is the sum of net-accumulation and sublimation) compared to the annual precipitation amount, extrapolated using data from La Serena (see text). The shaded area corresponds to the core section with "unknown age". 


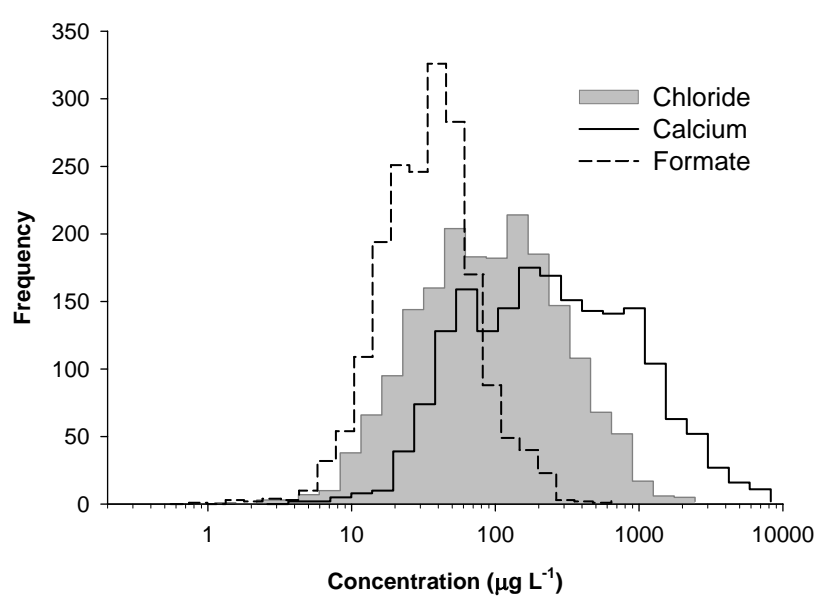

Fig. 5. Absolute frequency distribution histograms of chloride, calcium and formate concentration (1901 samples divided in 25 bins).

(Ginot et al., 2001a). In the Cerro Tapado record, chloride seems to be the best tracer of sublimation since the increase of chloride concentration in the surface snow layer is proportional to the water loss by sublimation and is not affected by dry deposition of sea salt. The amount of water lost by sublimation may thus be quantified from the chloride enrichment in each annual surface layer formed during the dry season. Assuming that only the upper snow layers are exposed to post-depositional processes, the deeper snow should keep its original composition. In order to obtain the mean concentration of chloride in fresh snow (not influenced by sublimation), we calculated the concentration frequency distribution of all ice core samples (1901 samples divided in 25 bins on a logarithmic scale).

Figure 5 illustrates the resulting frequency distributions of the three ions chloride, formate and calcium, which are influenced differently by sublimation (Ginot et al., 2001a). Formate forms volatile formic acid and is not enriched by sublimation. Consequently a mono-modal distribution is observed, representing the initial concentrations in fresh snow. Chloride is enriched in the surface layer by sublimation and shows a broader distribution with a bi-modal shape. The mode at $50 \mu \mathrm{g} \mathrm{L}^{-1}$ represents the concentrations in fresh snow, whereas the mode at $145 \mu \mathrm{g} \mathrm{L}^{-1}$ is due postdepositional enrichment. The distribution of calcium is even broader and has a third mode, which we attribute to dry deposition (Ginot et al., 2001a).

Accordingly, chloride concentrations higher than the fresh snow level of $50 \mu \mathrm{g} \mathrm{L}^{-1}$ were considered to result from enrichment by sublimation. With this assumption annual sublimation rates could be calculated from the chloride concentration record.

Figure 4 depicts the obtained mass balance terms on a temporal scale: Fig. 4a, lower part, shows annual sublimation, which fluctuates between 1 and $1237 \mathrm{~mm}$ weq with a mean annual value of $327 \mathrm{~mm}$ weq between 1962 and 1999. The upper part of Fig. 4b illustrates annual total accumulation, being the sum of net accumulation and sublimation, annual data for the period 1963-1999, and annual mean over 36 years before. A mean annual total accumulation rate of $539 \mathrm{~mm}$ weq is obtained for 1999-1962. During some hydrological years such as 1981, sublimation yields to a loss of $84 \%$ of the total accumulation. For other years, this ablation is a few percent only. The mean annual ablation due to sublimation amounts to 46\% for the period 1962-1999.

In order to validate this method of sublimation reconstruction using the chloride concentration profile, we applied the sublimation rates to correct the measured ${ }^{210} \mathrm{~Pb}$ activity profile. ${ }^{210} \mathrm{~Pb}$ in the atmosphere is usually attached to fine aerosol particles and is therefore deposited onto the glacier during snowfall, whereas the contribution of dry deposition is negligible. Since ${ }^{210} \mathrm{~Pb}$ cannot be volatilized after deposition, a similar enrichment due to sublimation as observed for chloride is expected. Strong fluctuations of the ${ }^{210} \mathrm{~Pb}$ activity with enrichment located on the same depth levels as chloride indicate that this is indeed the case (Fig. 6a).

The effect of the sublimation on ${ }^{210} \mathrm{~Pb}$ activity was corrected using the sublimation estimates deduced from the chloride record. For each ${ }^{210} \mathrm{~Pb}$ sample, the corresponding sample width was "stretched" by addition of the associated sublimation value, and the ${ }^{210} \mathrm{~Pb}$ activity was proportionally "dissolved", resulting in a much longer corrected profile. The resulting raw profile is illustrated in Fig. 6b. The total depth increased from $27.8 \mathrm{~m}$ weq net-accumulation to $78 \mathrm{~m}$ weq total accumulation. Indeed, most of the pronounced peaks from the primary data (Fig. 6a) are now removed, which supports the assumption that they represent an artifact coming from the sublimation post deposition enrichment. At $41 \mathrm{~m}$ weq the corrected activity (dashed curve in Fig. 6b) drops from $3 \mathrm{mBq} \mathrm{kg}{ }^{-1}$ to a level of about $0.7 \mathrm{mBq} \mathrm{kg}^{-1}$. This value of $0.7 \mathrm{mBq} \mathrm{kg}^{-1}$ was assumed as background level and subtracted to give the blank-corrected profile (thick line in Fig. 6b). The linear regression of the logarithmic sublimation and blank corrected ${ }^{210} \mathrm{~Pb}$ activity yields a y-axis intercept of $A_{0 c o r r}=34 \mathrm{mBq} \mathrm{kg}{ }^{-1}$ and an annual total accumulation of $465 \mathrm{~mm}$ weq, in reasonable agreement with the values listed in Table 2 . The drop at $41 \mathrm{~m}$ corresponds to a time lapse of at least 35 years.

\subsubsection{Melting}

The firn/ice temperature of $\leq-8.5^{\circ} \mathrm{C}$ throughout the core (see Fig. 3) allows surface meltwater to percolate only a few centimeters before refreezing in sub-surface ice layers ("recrystallization zone"). Thus, melting is not an important ablation process, but is nevertheless important for the energy balance. The firn densification model by Herron and Langway (1980), based on a firn temperature of $-12^{\circ} \mathrm{C}$ at $10 \mathrm{~m}$ depth and mean annual net-accumulation of $315 \mathrm{~mm}$ weq $\mathrm{y}^{-1}$, served to describe the theoretical metamorphosis of 

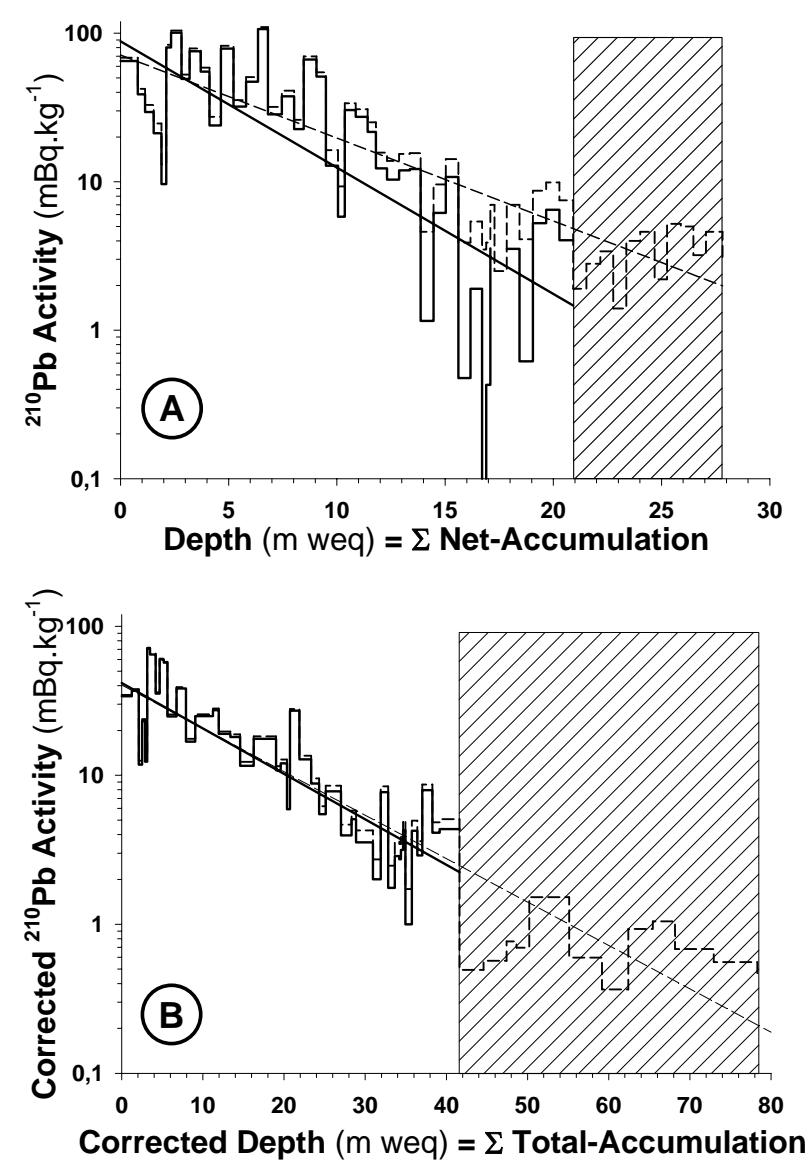

Fig. 6. Measured (a) and sublimation corrected (b) ${ }^{210} \mathrm{~Pb}$ activity profiles with linear regression lines. Dashed and thick lines represent raw and blank corrected values respectively. The grey zone represents the ice core section with "unknown age".

snow to ice up to a firn density of $0.8 \mathrm{~g} \mathrm{~cm}^{-3}$. As shown in Fig. 3, the measured density is often higher than modeled as a result of sub-surface re-crystallization layers. The differences observed between measured and modeled densities for each $70 \mathrm{~cm}$ long core sections were used to calculate the proportion of ice lenses and related surface melting. A mean annual melt of $40 \mathrm{~mm}$ was deduced for the period 1962-1999 and $33 \mathrm{~mm}$ for the lower part. The large difference between mean annual sublimation and melting is caused by short positive temperature periods responsible for melting and extended time periods where climatic conditions favor sublimation (vapor pressure deficit, global radiation and wind speeds) (Vuille, 1996; Kull and Grosjean, 2000).

3.2 Climate parameter reconstruction for the modern period: 1920-1999

The resulting annual mass balance parameters were compared with the Southern Oscillation Index (SOI) and with extrapolated annual precipitation. The SOI characterizes the cold (positive values, La Niña) and warm phases (negative values, El Niño) of the El Niño-Southern Oscillation (ENSO). In Fig. 4a, annual net-accumulation and sublimation are compared with the annual mean values (March to March) of the monthly SOI data (source: Commonwealth, Bureau of Meteorology). $70 \%$ of the above average annual net-accumulation values (average $316 \mathrm{~mm}$ weq from 19621999 ) correspond to wet phases of ENSO (indicated by arrows in the WET window). On the opposite, only $50 \%$ of above average $327 \mathrm{~mm}$ sublimation events correspond to ENSO dry phases (indicated by arrows in the DRY window). In addition, high annual net-accumulation values are generally associated with lower sublimation and vice versa. These results support the interpretation that the precipitation regime and climatic conditions in the region of Cerro Tapado are strongly influenced by the Westerlies circulation regime with higher total-accumulation during El Niño years, but that during La Niña dry phases, eastern moisture inputs and cloud cover may reduce the sublimation.

In order to compare the reconstructed total-accumulation rates with direct precipitation measurements, data from La Serena $\left(29^{\circ} 55^{\prime} \mathrm{S}, 71^{\circ} 12^{\prime} \mathrm{W}, 146 \mathrm{~m}\right)$ for the time period 1920 to 2000 (A. Montecinos, personal communication) were extrapolated to the altitude of Cerro Tapado using a linear altitudinal gradient of $4.3 \mathrm{~mm} / 100 \mathrm{~m}$ deduced from annual precipitation means for 1977-1988 coming from 6 precipitation measurement stations along the Elqui valley: La Serena (146 m), Almendral, Rivadavia, Pisci Elqui (1250 m), La Ortiga and La Laguna (3100 m) (Begert, 1999). The mean annual precipitation estimated in this way was $315 \mathrm{~mm}$ for the period 1962-1999 (Fig. 4b), which is somewhat lower than the $539 \mathrm{~mm}$ given in Table 2. One possible reason might be occasional convective precipitation events approaching from the east that are not taken into account in such an extrapolation but observed along the Elqui valley (Bergert, 1999). Furthermore, higher peaks in the region such as Cerro. Olivares $\left(30^{\circ} 17^{\prime} \mathrm{S} 69^{\circ} 54^{\prime} \mathrm{W}, 6252 \mathrm{~m}\right)$ are currently free of glaciers. The presence of the Tapado glacier in a generally glacier-free environment emphasizes the local atypical climatic-glaciological conditions with increased accumulation rates. We consider two processes to be relevant. First, re-deposition of snow and snow-cornices along the crest was observed and may account for the locally enhanced accumulation rates. Second, Co. Tapado is located directly in front of the Paso del Agua Negra. Ammann (1996) showed that moisture is preferentially transported along valleys, which results in locally enhanced cloud cover and precipitation.

The trends in both, extrapolated precipitation and totalaccumulation, reflect a drier period from 1973 to 1981, and two wet episodes between 1962 and 1973, and after 1981. The strong increase of total accumulation to $1310 \mathrm{~mm}$ for the lowermost part of the core can not be explained by precipitation rates of the last century. 
Table 3. Climate reconstruction from the accumulation history in the core using the mass balance model from (Kull and Grosjean, 2000, and Kull et al., 2002).

\begin{tabular}{lllll}
\hline Parameter & $1998 / 1999$ & $1920 / 1999$ & $23.5 \mathrm{~m}$ - bottom & Difference \\
\hline & Measured/modeled & Modern average & Paleo-conditions & Paleo/Modern \\
\hline Mean annul Temp. $\left({ }^{\circ} \mathrm{C}\right)$ & -11.5 & $-12.4 \pm 0.2$ & $-15 \pm 1.5$ & $-3( \pm 1.5)$ \\
Total accumulation $(\mathrm{mm} / \mathrm{y})$ & 750 & $540 \pm 45$ & $830 \pm 50$ & $+290 \pm 150$ \\
Winter accumulation $(\mathrm{mm})$ & 500 & $310 \pm 45$ & $780 \pm 50$ & $+470 \pm 100$ \\
Summer accumulation $(\mathrm{mm})$ & 250 & $230 \pm 45$ & $50 \pm 50$ & $-180 \pm 100$ \\
Sublimation $(\mathrm{mm} / \mathrm{y})$ & 490 & 240 & 620 & +380 \\
Net accumulation $(\mathrm{mm} / \mathrm{y})$ & 260 & 300 & 210 & -80 \\
\hline
\end{tabular}

\subsection{Paleoclimate}

Between $23.5 \mathrm{~m}$ weq depth and bedrock, direct dating of the ice core was not possible. Based on annual layers counting, this core section must be older than A.D. 1921. The presence of stretched gas bubbles (see Fig. 2) and low ice temperature near bedrock $\left(-12.4^{\circ} \mathrm{C}\right)$ yields evidence for a much older ice body frozen to bedrock. This hypothesis is supported by the high ice density of this layer corresponding to the third stage of densification with compression of the bubbles under past higher glacier thickness pressure (e.g. Herron and Langway, 1980). Furthermore, the reconstructed mass balance terms for this lowermost part of the core differ markedly from the 20th century conditions (Table 2), especially for the reconstructed sublimation. Therefore, this ice must have been formed under very different climatic conditions in the more distant past. The mass balance model used to set up the relationship between climatic conditions and accumulation/ablation parameters on Cerro Tapado (Kull and Grosjean, 2000; Kull et al., 2002) was used to model related climatic conditions recorded in this ice body (Table 3 ). To explain such anomalous annual mean values, major climatic changes in comparison to modern conditions are required. The reconstructed accumulation history in this part of the core must have been driven by massive sublimation losses during the buildup of the glacier (Table 3). The climatic interpretation, consistent with both, the ice core data and the climate-mass-balance model (Kull and Grosjean, 2000; Kull et al., 2002), points to lower temperatures $\left(-3 \pm 1.5^{\circ} \mathrm{C}\right)$, higher annual precipitation $(290 \pm 150 \mathrm{~mm})$ and increased seasonality in the moisture supply (Table 3 ). High precipitation in the humid winter season is responsible for the necessary accumulation while the extended dry season relates to the pronounced sublimation. Today the timing of this climatic regime remains unclear. However, the presence of a time and accumulation hiatus of unknown age and duration is clearly indicated and raises concerns and speculations.

The formation of the upper part of the Cerro Tapado glacier must therefore have occurred after previous climatic conditions have caused a complete ablation down to
$23.5 \mathrm{~m}$ weq. To reach a negative net-accumulation, a reduction of the current annual total-accumulation by more than $270 \mathrm{~mm}$ weq is necessary. Assuming extremely dry climatic conditions such as those occurring in the center of the "South American Arid Diagonal" (around $25^{\circ} \mathrm{S}$ ) at this altitude (summer precipitation $=50 \mathrm{~mm}$, winter precipitation $=230 \mathrm{~mm}$ ), a maximum annual negative mass balance of $-515 \mathrm{~mm}$ is estimated after Kull and Grosjean (2000). This would require $\sim 50$ years of extremely dry conditions for a complete ablation of the actual ice mass on the summit plateau. If ablation by sublimation alone would have caused this reduction of the ice mass, a significant concentration peak in conservative chemical species would be expected which is not the case at $23.5 \mathrm{~m}$ weq. This implies that the hiatus at this depth must be explained by ice flow over the basal frozen ice body combined with ablation after the formation of the basal ice body.

When did the buildup of the lower part start? As shown by mass balance modeling, extremely dry periods could not have persisted over longer periods since the glacier formation. They would have caused a complete ablation of the ice mass. Observations from the Agua Negra glacier (Brackebusch, 1892) located a few kilometers east in Argentina $\left(30^{\circ} 15^{\prime} \mathrm{S}, 69^{\circ} 50^{\prime} \mathrm{W}\right)$ report a markedly greater extension than actual of this glacier in A.D. 1890 and indicate therefore a "glacier friendly" (cool/humid) climate during periods of the Little Ice age. This implies that also Cerro Tapado glacier existed in this time. On the other side, the dry mid Holocene with substantially reduced precipitation (e.g. Lamy et al., 1999; Maldonado and Villagran, 2002; Jenny et al., 2002a) would not have allowed any glacier growth in the region.

After the dry mid Holocene, a first ( $<2600$ BP) substantial glacier advance is recorded in the area around $30^{\circ} \mathrm{S}$ (Grosjean et al., 1998). Those moraines are also existing in the surroundings of Cerro Tapado and therefore confirm a greater extension of Cerro Tapado glacier than today. As shown by Kull et al. (2002), substantial glacier growth in the region is linked to precipitation increase and temperature depression. Those findings are in agreement with the reconstructed 
climatic conditions for the bottom ice mass. The derived strong link of Cerro Tapado mass balance and ENSO for recent decades may imply a similar relationship for the past. The modeled increased hydrological seasonality with enhanced winter precipitation and dry summers could therefore link to stronger ENSO activity during this glacier buildup period, as also suggested from sediment cores offshore Chile (Lamy et al., 1999), Lake sediment records in central Chile (Jenny et al., 2002a) and archaeologically based paleoclimatic data from the Peruvian coast (Sandweiss, 2003). On the other hand, it remains speculative if Cerro Tapado glacier would have survived e.g. long lasting dry periods with likely persistently weak El Ninos around BC 200 and AD 250 (Jenny at al., 2002b) and in medieval times during A.D. 8001250 as recorded in different ENSO sensitive archives (e.g. Rein et al., 2004).

\section{Conclusions}

Tropical glacier ice cores have often been used as paleoclimatic and environmental archives based on the interpretation of chemical and stable isotope records. However, this study performed on a $36 \mathrm{~m}$ long ice core from subtropical Cerro Tapado glacier shows how drastically secondary effects such as sublimation may perturb primary information. Fortunately, sublimation leaves a footprint in the chemical record which can be used to reconstruct the original situation. This study shows how, on the basis of chemical trace analysis and the measurement of tritium and ${ }^{210} \mathrm{~Pb}$, the mass-balance parameters sublimation, melting and total-accumulation as a function of time can be deduced. This reconstruction reveals that, for the period 1962-1999, mean water loss due to sublimation amounted to $46 \%$ of total precipitation. Occasional melting and associated percolation was limited to the surface layer as a result of the low snow/firn temperature. The inferred annual total accumulation was compared with the SOI, which gives evidence that at Cerro Tapado the precipitation and ablation regimes are mainly influenced by ENSO conditions.

Based on ice core stratigraphy, mass balance reconstruction and ${ }^{210} \mathrm{~Pb}$ dating, a hiatus in the ice body was found at a depth of $23.5 \mathrm{~m}$ weq. Below $23.5 \mathrm{~m}$ weq., the reconstruction suggests more humid and colder climate conditions with very pronounced precipitation seasonality, in marked contrast to 20th century conditions. This part has been formed under different climate conditions. Unfortunately the basal body is not dated yet. Therefore, it remains speculative, when the reconstructed climate conditions allowed starting the glacier buildup. Based on regional paleoclimatic proxy data, we conclude that the bottom ice mass was formed after the dry mid-Holocene, under humid and cool climate conditions probably related to intensified ENSO activity.
Acknowledgements. We would like to thank J. Quinteros (Dirección General de Aguas, Chile), A. Giannini (Universidad de Chile, Santiago), B. Zweifel (ETH Zürich) for their contribution to the fieldwork. The help of M. Grosjean and H. Veit (University of Bern) and A. Rivera (Universidad de Chile, Santiago) in organizing our expedition as well as the active support of H. P. Erismann, Swiss ambassador in Santiago de Chile, is highly acknowledged. Appreciation is expressed to the Chilean Army (Regimiento de Infantería No. 21 "Arica") for the support of the fieldwork, to Swisscargo for transporting the ice samples and to the Aargauer Zentralmolkerei for storing the ice. This work was carried out in the framework of the Swiss National Science Foundation, Projects 21-50854.97 and 21-50854.99. I appreciate the constructive comments from both anonymous reviewers.

Edited by: V. Masson-Delmotte

\section{References}

Ammann, C.: Climate change in den trockenen Anden: Aktuelle Niederschlagsmuster, Geographica Bernensia, G46, 81127, 1996.

Ammann, C., Jenny, B., Kammer, K., and Messerli, B.: Late Quaternary Glacier response to humidity changes in the arid Andes of Chile (18-29 S), Palaeogeogr., Palaeoclimatol., Palaeoecol., 172(3-4), 313-326, 2001.

Begert, M.: Klimatologische Untersuchungen in der weiteren Umgebung des Cerro Tapado, Norte Chico, Chile, Master degree Thesis, University of Berne, Switzerland, 1999.

Brackebusch, L.: Die Kordillerenpässe zwischen der argentinischen Republik und Chile, Zeitschr. Ges. Erdk, 27, 20-36, 1892.

Bradley, R. S.: Paleoclimatology; reconstructing climates of the Quaternary, International Geophysics Series, Vol. 64. Academic press, London, 1999.

Correia, A., Freydier, R., Delmas, R. J., Simões, J. C., Taupin, J.D., Dupré, B., and Artaxo, P.: Trace elements in South America aerosol during 20th century inferred from a Nevado Illimani ice core, Eastern Bolivian Andes (6350 m a.s.1.), Atmos. Chem. Phys., 3, 2143-2177, 2003, http://www.atmos-chem-phys.net/3/2143/2003/.

De Angelis, M., Simões, J. C., Bonnaveira, H., Taupin, J. D., and Delmas, R. J.: Volcanic eruptions recorded in the Illimani ice core (Bolivia): 1918-1998 and Tambora periods, Atmos. Chem. Phys., 3, 1725-1741, 2003, http://www.atmos-chem-phys.net/3/1725/2003/.

Eichler, A., Schwikowski, M., Gäggeler, H. W., Furrer, V., Synal, H. A., Beer, J., Saurer, M., and Funk, M.: Glaciochemical dating of an ice core from upper Grenzgletscher (4200 m a.s.l.), J. Glaciol., 46(154), 507-515, 2000.

Escobar, F., Casassa, G., and Pozo, V.: Variaciones de un glaciar de montaña en los Andes de Chile central en las últimas dos décadas, Bull. Inst. Fr. Etudes Andines, 24(3), 683-695, 1995.

Escobar, F. and Aceituno, P.: Influencia del fenomeno ENSO sobre la precipitacion nival en el sector andino de Chile Central, durante el invierno austral, Bull. Inst. Fr. Etudes Andines, 27(3), 753-759, 1998.

Francou, B., Ramirez, E., Cáceres, B., and Mendoza, J.: Glacier Evolution in the Tropical Andes during the Last Decades of the 20th Century: Chacaltaya, Bolivia, and Antizana, Ecuador, AM- 
BIO: A Journal of the Human Environment, 29(7), 416-422, 2000.

Francou, B., Vuille, M., Wagnon, P., Mendoza, J., and Sicart, J.E.: Tropical climate change recorded by a glacier in the central Andes during the last decades of the twentieth century: Chacaltaya, Bolivia, $16^{\circ}$ S, J. Geophys. Res., 108(D5), 4154, doi:10.1029/2002JD002959, 2003.

Ginot, P., Kull, C., Schwikowski, M., Schotterer, U., and Gäggeler, H. W.: Effects of post-depositional processes on snow composition of a subtropical glacier (Cerro Tapado, Chilean Andes), J. Geophys. Res., 106(D23), 32 375-32 386, 2001a.

Ginot, P., Schwikowski, M., Schotterer, U., Gäggeler, H. W., Francou, B., Gallaire, R., and Pouyaud, B.: Potential for climate variability reconstruction from Andean glaciochemical records, Ann. Glaciol., 35, 443-450, $2001 b$.

Ginot, P., Stampfli, F., Stampfli, D., Schwikowski, M., and Gäggeler, H. W.: FELICS, a new ice core drilling system for high-altitude glaciers, Memoirs of National Institute of Polar Research, 56 (Special Issue), 38-48, 2002.

Grosjean, M., Geyh, M. A., Messerli, B., Schreier, H., and Veit, H.: A late Holocene $(<2600 \mathrm{BP})$ glacial advance in the southcentral Andes $\left(29^{\circ} \mathrm{S}\right)$, northern Chile, The Holocene, 8(4), 473479, 1998

Hardy, D., Williams, M. W., and Escobar, C.: Near-surface faceted crystals, avalanches and climate in high-elevation, tropical mountains of Bolivia, Cold Regions Science and Technology, 33(2-3), 291-302, 2001.

Herron, M. M. and Langway, C.C.: Firn densification: an empirical model, J. Glaciol., 25, 373-385, 1980.

Hou, S. and Qin, D.: The effect of postdepositional process on the chemical profiles of snow pits in the percolation zone, Cold Regions Science and Technology, 34(2), 111-116, 2002.

Jenny, B., Valero-Garcés, B. L., Villa, R., Urrutia, R., Geyh, M., and Veit, H.: Early to mid-Holocene aridity in Central Chile and

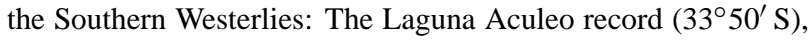
Quater. Res., 58, 160-170, 2002a.

Jenny, B., Valero-Garcés, B., Urrutia, R., Kelts, K., Veit, H., Appleby, P. G., and Geyh, M.: Moisture changes and fluctuations of the Westerlies in Mediterranean Central Chile during the last 2000 years: The Laguna Aculeo record ( $\left.33^{\circ} 50^{\prime} \mathrm{S}\right)$, Quater. Int., 87, 3-18, 2002b.

Knüsel, S., Ginot, P., Schotterer, U., Schwikowski, M., Gaeggeler, H. W., Francou, B., Simões, J. C., Petit, J. R., and Taupin, J. D.: Dating of two nearby ice cores from the Illimani, Bolivia, J. Geophys. Res., 108(D6), 4181, doi:10.1029/2001JD002028, 2002.

Kull, C. and Grosjean, M.: Late Pleistocene climate conditions in the north Chilean Andes drawn from a climate-glacier model, J. Glaciol., 46, 622-632, 2000.

Kull, C., Grosjean, M., and Veit, H.: Modeling Modern and Late Pleistocene glacio-climatological conditions in the North Chilean Andes (29 $\left.{ }^{\circ} \mathrm{S}-30^{\circ} \mathrm{S}\right)$, Climate Change, 52(3), 359-381, 2002.
Lamy, F., Hebbeln, D., and Wefer, G.: High resolution marine record of climatic change in mid-latitude Chile during the last 28000 years based on terrigenous sediment parameters, Quater. Res., 51, 83-93, 1999.

Maldonado, A. and Villagran, C.: Paleoenvironmental changes in the semiarid coast of Chile $\left(32^{\circ} \mathrm{S}\right)$ during the last 6200 cal years inferred from a swamp-forest pollen record, Quater. Res., 58, 130-138, 2002.

Minetti, J. L., Barbieri, P. M., Carletto, M. C., Poblete, A. G., and Sierra, E. M.: El regimen de precipitatiòn de la provincia de San Juan, Informe técnico, 8, CIRSAJ-CONICET, San Juan, 1986.

Rein, B., Lückge, A., and Siroco, F.: A major Holocene ENSO anomaly during the Medieval period, Geophys. Res. Lett., 31, L17211, doi:10.1029/2004GL020161, 2004.

Sandweiss, D. H.: Terminal Pleistocene through mid-Holocene archaeological sites as paleoclimatic archives for the Peruvian coast, Palaeogeography, Palaeoclimatology, Palaeoecology, 194, 23-40, 2003.

Schotterer, U., Schwarz, P., and Rajner, V.: From pre-bomb levels to industrial times. A complete tritium record from an ice core and its relevance for environmental studies, International Symposium on Isotope Technique in the Study of Past and Current Environmental Changes in the Hydrosphere and the Atmosphere, Vienna, 14-18 April 1997, 1998.

Schotterer, U., Stichler, W., and Ginot, P.: The influence of postdepositional effects on ice core studies: examples from the Alps, Andes, and Altai, in: Earth Paleoenvironments: Records preserved in Mid and Low Latitude Glaciers, edited by: Cecil, L. D., Thompson, L. G., Steig, E. J., and Green, J. R., Kluwer Academic/Plenum Publishers, 2005.

Stichler, W., Schotterer, U., Fröhlich, K., Ginot, P., Kull, C., Gäggeler, H. W., and Pouyaud, B.: The influence of sublimation on stable isotopes records from high altitude glaciers in the tropical Andes, J. Geophys. Res., 106(D19), 22 613-22 621, 2001.

Thompson, L. G., Mosley-Thompson, E., Bolzan, J. F., and Koci, B.: A 1500-Year Record of tropical precipitation in ice core from the Quelccaya ice cap, Peru, Science, 229, 971-973, 1985.

Thompson, L. G., Mosley-Thompson, E., Davis, M. E., Lin, P.-N., Henderson, K. A., Cole-Dai, J., Bolsan, J. F., and Lui, K.-B.: Late glacial stage and Holocene tropical ice core records from Huascaran, Peru, Science, 269, 46-50, 1995.

Thompson, L. G., Davis, M., Mosley-Thompson, E., Sowers, T. A., Henderson, K. A., Zagorodnov, V. S., Lin, P. N., Mikhalenko, V. N., Campen, R. K., Bolzan, J. F., Cole-Dai, J., and Francou, B.: A 25000 -year tropical climate history from Bolivian ice cores, Science, 282, 1858-1864, 1998.

Vuille, M.: Zur raumzeitlichen Dynamik von Schneefall und Ausaperung im Bereich des südlichen Altiplano, Südamerika, Ph.D. thesis, University of Berne, Switzerland, 1996. 